\title{
Effect of dietary fat source on humoral immunity response of broiler chickens
}

\author{
Einfluss der Futterfettquelle auf die humorale Immunantwort von Broilern
}

M. Poorghasemi', A. Seidavi', A.A.A. Qotbi', J.R. Chambers ${ }^{2}$, V. Laudadio ${ }^{3}$ and V. Tufarelli ${ }^{3}$

${ }^{1}$ Department of Animal Science, Rasht Branch, Islamic Azad University, Rasht, Iran
${ }^{2}$ Guelph Food Research Center, Agriculture and Agri-Food Canada, Guelph, Ontario, Canada
${ }^{3}$ Department of Emergency and Organ Transplantation, Section of Veterinary Science and Animal Production, University of Bari 'Aldo Moro', Valenzano, Italy

Correspondence: vincenzo.tufarelli@uniba.it

Manuscript received 19 March 2015, accepted 27 May 2015

\section{Introduction}

In broiler chicken production, feed represents a major proportion of production costs (DONOHUE and CUNNINGHAM, 2008). According to VAN DER KLIS et al. (2010), dietary energy accounts for $70-75 \%$ of feed costs. In the past, cereal grains have been the major source of energy in broiler diets; however, dietary fats have also been used more recently as high energy components. They are economical, often originating as by-products from the rendering industries and oils from oil seed processing. Literature reviews concerning fat in poultry diets (BAIAO and LARA, 2005; SHivAZAD and SeIDAVI, 2006; Murugesan, 2013) list many benefits. These include: i) a high energy content; ii) a source of essential fatty acids (n-3 and n-6); iii) a source of fat soluble vitamins (A, D, E and K) and lecithin; iv). Fat supplementation of rations gives rise to an "extra-caloric" effect by improving digestion of other dietary compounds. This "extra-caloric effect" has been attributed to decreased rate of passage of digestive tract content and hence, improved digestion and absorption of nutrients, synergistically enhanced absorption of saturated fatty acids when accompanied by unsaturated fatty acids, reduced heat increment of diets with fat which improves utilisation of metabolisable energy and finally that added fat may improve physical characteristics and palatability of the diet promoting increased feed consumption. Fats do require care in their inclusion into poultry diets depending on their gross energy and the metabolisability. Ruminant animal fats, especially tallow, tend to reduce rate of passage of the digesta in the intestines and to increase abdominal fat levels (POORGHASEMI et al., 2013). On the other hand, fats with higher levels of unsaturated fatty acids, especially linoleic acids, often from plants, improve nutrient partitioning to enhance growth but not abdominal fatness (NEWMAN et al., 2002; NTAMBI et al., 2002). Mixtures, or blends, of fats and oils of animal and vegetable origin with combinations of unsaturated and saturated fatty acids tend to be used to optimise the metabolisable energy of rations. The recommended ratio of unsaturated to saturated fatty acid is at least 4:1 with a minimum of $50 \%$ linoleic acid. The above issues prevail provided the fats are of suitable quality and are neither contaminated nor rancid. There have been various studies and reviews on the effects of types of dietary fat or fatty acids on the different components of immunity of broilers and other avian species are available. The effects of dietary fatty acids on immune responses to common food-borne bacterial infections in chickens have been reviewed (HARRISON et al., 2013). Different types of dietary fatty acids, short-chain or medium-chain polyunsaturated, had variable effects on bacterial clearance and disease outcome through suppression or activation of immune responses (HARRISON et al., 2013). Some fat sources in broiler chicken diets have been reported to increase the incidence of ascites, sudden death and the incidence of liver abnormalities (ROTTER et al., 1985; SANZ et al., 2000). The addition of $2 \%$ fish oil to broiler diets significantly increased serum antibody (mostly IgM) to SRBCs (HOSSEINI-MANSOUB and BAHRAMI, 2011) apparently stimulating development of immune response. The effect of essential fatty acids on poultry immune aspects has been tested as well. The effects of dietary n-6:n-3 fatty acid ratios of 10 , six and two on immune and reproductive systems of layer pullets were studied to 22 weeks (PILEVAR et al., 2011). 
Antibody titers in response to SRBC injection and ND, IB, IBD and Avian Influenza (AI) vaccinations were measured. Diets with a ratio of 10 increased antibody production for AI at 10 and 14 weeks and for ND at 14 weeks. Those with a ratio of six increased antibody production for IB and IBD vaccination at 14 weeks; however, SRBC injection had no effect for any ratio. Diets with a ratio of two tended to reduce rate of sexual maturity and egg production. Full-seed dietary oil seeds (flax seed and canola seed) tested for effects on n-3 fatty acid enrichment of meat of broiler chicken (KAMRAN et al., 2009) increased levels of $n-3$ fatty acids and decreased levels of arachidonic acid and ratios of n-6:n-3 polyunsaturated fatty acids in meat. Conjugated linoleic acids (CLA) consist of a group of geometric and positional isomers that are structurally similar to linoleic acid; however, their two double bonds are conjugated instead of methylene interrupted. The impact of dietary CLA on cell mediated immunity and other responses of chickens as well as laboratory and other animals have been reviewed (NTAMBI et al., 2002). The CLAs were concluded to modulate the adverse effects of immune stimulation. The effects of dietary fat or fatty acids on the different components of immunity of broiler and other chickens tend to vary and appear to depend upon the immune stimulant and the response mechanism involved. Moreover, many studies were performed in laboratory environments. Consequently, the utilisation of fats to optimise commercial broiler performance requires an evaluation of available supplies of fats for their impact on broiler immunity under commercial growth environments. Therefore, this study examined the effect of various single and combined dietary fat sources on cell mediated, immune organ size and humoral or antibody response to viral disease vaccination of commercial broilers to attempt to clarify these issues.

\section{Material and Method}

\section{Animals and diets}

This experiment was conducted in 2012 in the poultry facility of Islamic Azad University, Rasht Branch, Rasht, Iran. Two hundred male Ross 308 chicks were assigned to one of five treatments, with four replicates including 10 birds, as follow: $4 \%$ beef tallow (TO), $4 \%$ canola oil (CO), $4 \%$ sunflower oil (SO), $2 \%$ beef tallow $+2 \%$ canola oil (TOCO), and $2 \%$ beef tallow $+2 \%$ sunflower oil (TOSO) with 10 birds per replication. Treatments were randomly assigned and each group of 10 birds was raised in a $1.5 \times 1.0 \mathrm{~m}$ wire mesh pen within the hall. The facility and equipment were disinfected prior to bird placement. Poultry facility had thermostatically controlled curtains and cross-ventilation as well as lighting program (LAUDADIO et al., 2012). Pens were equipped with a pan feeder, a manual drinker and wood shavings. Drinkers were regularly washed to prevent faecal and microbial contaminations. For this research, the care and use of broilers, and the experimental procedures described were approved by the Islamic Azad University Ethics Committee.

\section{Vaccination and sheep red blood cell injection}

A total of five birds per replication were given five different vaccinations or injections (IBV, NDV, IBDV, SRBC injection no. 1, SRBC injection no. 2, respectively) at varying time intervals as shown in Table 1. Infectious bronchitis virus (IBV) strain H120 vaccine was provided at day one, d 16, and d 23. Newcastle Disease Virus (NDV) strain Viscerotropic velogenic vaccine was provided at days 8, 20 and 27. Infectious bursal disease virus (IBDV) strain 52/70 vaccine was provided at days 14, 23 and 30. The recommendations of the suppliers were followed for vaccine preparation prior to vaccination via drinking water which followed a period of water removal. On the day of treatment, $0.5 \mathrm{ml}$ of $0.5 \%$ SRBC was injected subcutaneously into two selected chicks according to Table 1 . Broilers injected with SRBC were marked for recovery on sampling days.

Table 1. Vaccination or injection schedule with sampling days after placement of broilers

Impf- bzw. Injektionsprotokoll mit den Probensammeltagen nach dem Einsetzen der Broiler

\begin{tabular}{|c|c|c|c|c|}
\hline $\begin{array}{l}\text { Vaccine/ } \\
\text { Injection }^{1}\end{array}$ & $\begin{array}{l}1^{\text {st }} \text { vaccination/ } \\
\text { injection }\end{array}$ & $\begin{array}{l}2^{\text {nd }} \text { vaccination/ } \\
\text { injection }\end{array}$ & $1^{\text {st }}$ sampling & $2^{\text {nd }}$ sampling \\
\hline IBV & 1 & 16 & 23 & $\mathrm{~N} / \mathrm{A}$ \\
\hline NDV & 8 & 20 & 27 & $\mathrm{~N} / \mathrm{A}$ \\
\hline IBDV & 14 & 23 & 30 & $\mathrm{~N} / \mathrm{A}$ \\
\hline SRBC & 23 & 35 & 29 & 41 \\
\hline
\end{tabular}

\footnotetext{
${ }^{1}$ Vaccines were supplied via drinking water following a period of water removal; SRBC were injected.
} 


\section{Samples and Analysis}

Blood samples of $1.5 \mathrm{ml}$ of blood from the wing vein broilers were collected at the appropriate dates, the serum separated and samples chilled until analyses. The SRBC and NDV response was determined using HI whereas the IBD and IBDV responses were determined using an ELISA kit (Cistron Biotechnology, Pine Brook, NJ). On the final day of the experiment, one bird from each replication was killed by cervical dislocation and necropsied. Spleen, thymus, and bursa of Fabricius were removed and weighed. Spleen, thymus, and bursa of Fabricius weights were used to calculate the percent of total body mass associated with the organ. Ingredients and nutrient composition of the diets used in this study is shown in Tables 2 and 3, respectively. Broilers had ad libitum access to feed and water. Diets were formulated to be isoenergetic and were formulated to meet or exceed broiler nutrient requirements (NRC, 1994). Samples of the diet were ground in a hammer mill with a $1 \mathrm{~mm}$ screen and analysed in triplicate according to the methods of AOAC (2000). The metabolisable energy (ME) of the basal diet was estimated using the Carpenter and Clegg equation (LEESON and SUMMERS, 2001).

Table 2. Ingredients composition of the basal diets

Zusammensetzung der Basis-Futterrationen

\begin{tabular}{|c|c|c|c|}
\hline Ingredient (g/kg) & Starter & Grower & Finisher \\
\hline Maize & 545 & 585 & 637 \\
\hline Soybean meal (48\% CP) & 375 & 335 & 295 \\
\hline Oil or Fat & 40 & 40 & 40 \\
\hline DL-Methionine & 180 & 210 & 150 \\
\hline DL-Lysine & 70 & 90 & 10 \\
\hline Ca22\%:P18\% & 16 & 15 & 15 \\
\hline $\mathrm{CaCO}_{3}(\mathrm{mg} / \mathrm{kg})$ & 12 & 12 & 11 \\
\hline $\mathrm{NaHCO}_{3}(\mathrm{mg} / \mathrm{kg})$ & 120 & 140 & 100 \\
\hline $\mathrm{NaCl}(\mathrm{mg} / \mathrm{kg})$ & 230 & 260 & 250 \\
\hline Vitamin-mineral premix & 6 & 6 & 6 \\
\hline
\end{tabular}


Table 3. Calculated nutrient analysis of basal diet

Kalkulierte Nährstoffgehalte der Basisfutterrationen

\begin{tabular}{|c|c|c|c|}
\hline Ingredient & Starter & Grower & Finisher \\
\hline Crude protein (\%) & 21.0 & 19.6 & 18.2 \\
\hline ME (MJ/kg) & 12.6 & 12.7 & 12.9 \\
\hline Lysine $(\mathrm{g} / \mathrm{kg})$ & 12.7 & 11.0 & 9.7 \\
\hline Methionine (g/kg) & 4.7 & 4.2 & 3.6 \\
\hline Met+Cys (g/kg) & 9.4 & 8.4 & 7.6 \\
\hline Tryptophan (g/kg) & 2.0 & 1.8 & 1.6 \\
\hline Arginine (g/kg) & 13.1 & 11.4 & 10.2 \\
\hline Iso-leucine (g/kg) & 10.4 & 9.5 & 9.4 \\
\hline Valine (g/kg) & 16.0 & 10.7 & 10.3 \\
\hline Leucine (g/kg) & 19.9 & 18.7 & 18.2 \\
\hline $\mathrm{Ca}(\mathrm{g} / \mathrm{kg})$ & 10.5 & 9.0 & 8.5 \\
\hline Available $\mathrm{P}(\mathrm{g} / \mathrm{kg})$ & 5.0 & 4.5 & 4.2 \\
\hline $\mathrm{Na}(\mathrm{g} / \mathrm{kg})$ & 210.4 & 196.0 & 181.8 \\
\hline $\mathrm{K}(\mathrm{g} / \mathrm{kg})$ & 5.0 & 4.0 & 4.0 \\
\hline $\mathrm{Mg}(\mathrm{mg} / \mathrm{kg})$ & 5.0 & 6.0 & 5.0 \\
\hline $\mathrm{Cu}(\mathrm{mg} / \mathrm{kg})$ & 16.0 & 16.0 & 18.0 \\
\hline I (mg/kg) & 1.25 & 1.25 & 1.25 \\
\hline $\mathrm{Fe}(\mathrm{mg} / \mathrm{kg})$ & 40.0 & 40.0 & 40.0 \\
\hline $\mathrm{Mn}(\mathrm{mg} / \mathrm{kg})$ & 120.0 & 120.0 & 120.0 \\
\hline Se (mg/kg) & 0.30 & 0.30 & 0.30 \\
\hline $\mathrm{Zn}(\mathrm{mg} / \mathrm{kg})$ & 100.0 & 100.0 & 100.0 \\
\hline Vitamin A (IU/kg) & 11000 & 9000 & 9000 \\
\hline Vitamin E (IU/kg) & 75.0 & 50.0 & 50.0 \\
\hline Vitamin K (mg/kg) & 3.0 & 3.0 & 2.0 \\
\hline Vitamin $B_{12}(\mathrm{mg} / \mathrm{kg})$ & 0.016 & 0.016 & 0.016 \\
\hline Riboflavin (mg/kg) & 8.0 & 6.0 & 5.0 \\
\hline
\end{tabular}

\section{Statistical Analysis}

The experiment was performed in a completely randomised design. Normality test was performed and if necessary an appropriate transformation was applied. Data were analysed with SPSS software (IBM Corporation, Armonk, NY) and average values were compared by the Tukey's test. The statistical model was as follows: $X_{i j}=M+T_{j}+e_{i j ;}$ where: $X_{i j}$ represents the value observed in each experiment; $M$ is the average of the whole population, $T_{j}$ represents the effects of each group or test diet and $\mathrm{e}_{\mathrm{ij}}$ represents the residual or error effect of each broiler.

\section{Results and Discussion}

Fat source had an impact on some cell-mediated measures of broiler immunity: thymus weight $(\mathrm{P}<0.05)$; thymus percent of total body mass $(\mathrm{P}<0.05)$; bursa of Fabricius percent of total body mass $(\mathrm{P}<0.05)$ as shown in Table 4 . The TO increased thymus weight ( 11.93 vs. 5.98 to $7.04 \mathrm{~g}$ ) and thymus percentage of total body mass (0.61 vs. 0.29 to $0.35 \%$ ) over the other treatments, which were not statistically different from each other. Bursa of Fabricius weights were not statistically different among treatments. Percentage of total body mass $(0.13 \%)$ of the TO group was higher $(\mathrm{P}<0.05)$ than TOSO $(0.05 \%)$, but was not distinguishable from $\mathrm{CO}$, SO, or TOCO. Fat source did not have a significant effect on spleen weight or spleen percentage of total body mass $(\mathrm{P}<0.05)$. A review by KIDD (2004) of nutritional modulation of broiler immunity led to the following conclusions: dietary oils have effects on the inflammatory response and improve immune system functions; fish oil can improve body weight and cellular immunity but not humoral immunity and can reduce inflammatory response after lipopolysaccharide injections; at low levels $<2 \%$ fish oils may be advantageous for improvements for broiler immunity, body weight and recovery from immunological challenges. 
Table 4. Treatment means and SEM of weight and percentage of total mass of spleen, thymus and bursa of Fabricius of broiler chickens Mittelwerte und SEM der Gewichte und Anteile von Milz, Thymus und Bursa of Fabricius der Broiler

\begin{tabular}{|c|c|c|c|c|c|c|}
\hline \multirow[b]{2}{*}{ Treatment $^{1}$} & \multicolumn{2}{|c|}{ Spleen } & \multicolumn{2}{|c|}{ Thymus } & \multicolumn{2}{|c|}{ Bursa of Fabricius } \\
\hline & g & $\%$ & g & $\%$ & g & $\%$ \\
\hline TO & $2.49 \pm 0.26$ & $0.127 \pm 0.096$ & $11.93^{b} \pm 1.87$ & $0.61^{b} \pm 0.09$ & $2.56 \pm 0.44$ & $0.13^{b} \pm 0.02$ \\
\hline $\mathrm{CO}$ & $2.25 \pm 0.16$ & $0.125 \pm 0.066$ & $6.88^{\mathrm{a}} \pm 0.88$ & $0.35^{\mathrm{a}} \pm 0.05$ & $2.04 \pm 0.43$ & $0.10^{\mathrm{ab}} \pm 0.01$ \\
\hline SO & $2.47 \pm 0.12$ & $0.121 \pm 0.054$ & $5.98^{\mathrm{a}} \pm 1.07$ & $0.29^{\mathrm{a}} \pm 0.03$ & $2.16 \pm 0.72$ & $0.10^{\mathrm{ab}} \pm 0.03$ \\
\hline TOCO & $2.46 \pm 0.11$ & $0.117 \pm 0.059$ & $7.04^{a} \pm 0.75$ & $0.31^{\mathrm{a}} \pm 0.02$ & $2.31 \pm 0.31$ & $0.10^{\mathrm{ab}} \pm 0.01$ \\
\hline TOSO & $2.84 \pm 0.32$ & $0.136 \pm 0.150$ & $6.81^{a} \pm 1.91$ & $0.31^{\mathrm{a}} \pm 0.02$ & $1.26 \pm 0.10$ & $0.05^{\mathrm{a}} \pm 0.02$ \\
\hline
\end{tabular}

Means in a column not sharing a common superscript letter are statistically different (P > 0.05). ${ }^{1}$ TO: $4 \%$ beef tallow; CO: $4 \%$ canola oil; SO: $4 \%$ sunflower oil; TOCO: $2 \%$ beef tallow + $2 \%$ canola oil; TOSO: $2 \%$ beef tallow + $2 \%$ sunflower oil.

Fat source appeared to have no impact on the humoral immune responses to NDV, IBDV or IBV vaccinations and SRBC injection as shown in Table 5. While differences in immune response were apparent, the differences based on fat source were not significant $(P>0.05)$. With regard to SRBC injection, this study is consistent with the results of two other studies (FRITSCHE and CASSITY, 1992; KAMRAN et al., 2009), but disagrees with other studies (HOSSEINIMANSOUB and BAHRAMi, 2011). Products with relatively high levels of essential fatty acids were evaluated in these studies. With regard to NDV vaccination, no response to dietary fat sources was found in this study but added cottonseed oil elevated NDV antibodies 18 days post vaccination (TORKI, 2002). Broilers fed isocaloric and isonitrogenous diets differing in levels $(0,0.75,1.5$ and $2.25 \%)$ of either fish oil or cotton seed and challenged with SRBCs or vaccinated for Newcastle disease virus were studied by TORKI (2002). Those fed $2.25 \%$ fish oil had the highest SRBC antibody titres following challenge whereas control broilers and those fed $2.25 \%$ cottonseed had the highest Newcastle disease virus antibody titer 18 days post challenge. On the other hand, full-seed oil seeds (flax seed and canola seed) did not differ in their effects on serum lipid content and antibody titer following SRBC challenge of broilers (KAMRAN et al., 2009).

Table 5. Treatment means and SEM of immune responses of broiler chickens after vaccination and/or injection Mittelwerte und SEM der Immunantwort der Broiler nach Impfung bzw. Injektion

\begin{tabular}{|c|c|c|c|c|c|}
\hline \multirow[b]{4}{*}{ Treatment $^{1}$} & \multicolumn{5}{|c|}{ Immune Response } \\
\hline & \multicolumn{2}{|c|}{ SRBC injection } & \multicolumn{3}{|c|}{ Vaccination } \\
\hline & 1st & 2nd & IBV & IBDV & NDV \\
\hline & $\log _{2} P F U$ & $\log _{2} P F U$ & $\log _{10}$ & $\log _{10}$ & $\log _{2}$ \\
\hline TO & $3.00 \pm 0.70$ & $5.25 \pm 0.47$ & $11,300 \pm 3,754$ & $237.25 \pm 156.01$ & $3.25 \pm 0.75$ \\
\hline $\mathrm{CO}$ & $2.25 \pm 0.25$ & $4.00 \pm 1.15$ & $13,301 \pm 2,537$ & $208.25 \pm 69.41$ & $4.50 \pm 0.95$ \\
\hline so & $3.25 \pm 0.75$ & $3.00 \pm 0.70$ & $3,783 \pm 2,185$ & $189.75 \pm 84.19$ & $3.75 \pm 0.75$ \\
\hline TOCO & $2.75 \pm 0.47$ & $2.75 \pm 0.75$ & $7,685 \pm 3334$ & $171.25 \pm 58.81$ & $3.50 \pm 0.95$ \\
\hline TOSO & $2.25 \pm 0.25$ & $4.00 \pm 0.57$ & $11,300 \pm 794$ & $44.50 \pm 25.11$ & $3.50 \pm 0.64$ \\
\hline
\end{tabular}

Means in a column not sharing a common superscript letter are statistically different $(\mathrm{P}>0.05)$. PFU, plaque-forming unit. ${ }^{1}$ TO: $4 \%$ beef tallow; CO: $4 \%$ canola oil; SO: $4 \%$ sunflower oil; TOCO: $2 \%$ beef tallow $+2 \%$ canola oil; TOSO: $2 \%$ beef tallow $+2 \%$ sunflower oil.

This study shows that vegetable and animal fat source had an impact on thymus weight, thymus percent of total body mass, and Bursa of Fabricius percent of total body mass. Animal fats, such as beef tallow as tested in this study, resulted in statistically greater organ weight and percentages. Fat source, whether animal, vegetable, or some 
combination of the two, had no impact on immune response. TORKI (2002) reported that the immune system of broiler chickens would respond to a two-stage SRBC injection. Although there should be an immune response to SRBC in broiler chickens, WANG et al. (2000) and FRITSCHE and CASSITY (1992) both reported that various fats or oils had no significant impact on immune response to SRBC. This is consistent with the results from this study, and contradict PILEVAR et al. (2011) who found that the use of different sources of dietary fat in broiler chickens poultry could have significant effects on the immune system compared to SRBC injection $(\mathrm{P}<0.05)$. The results of this study were consistent with TORKI (2002), who showed that feeding broilers on different levels of oil had no significant impact on antibody titers against NDV, IBD and IBDV.

\section{Conclusions}

For measures of cell-mediated immunity, differences in thymus weight and percentage, and Bursa of Fabricius percentage were found to be significant between broilers fed on diets containing different sources of dietary fat. Chickens fed on the diet with $4 \%$ tallow had the larger thymus weight and percent and tended to be the major source of difference. The spleen weight and percent and bursa of Fabricius weight of broilers were not affected by treatments. With regard to humoral immunity, no significant differences were observed for dietary fat source in antibody response to SRBC injection or antibody response to vaccinations for either NDV, IBDV or IBV. Similar studies in broilers are sparse and these results agree with most of them; however, they seem to disagree with some. Further research examining all factors contributing to interactions of dietary fat and broiler immunity is required to allow dietary fat manipulation to optimise broiler immunity.

\section{Summary}

An experiment was conducted to study the effect of dietary fat source on immune responses of broiler chickens reared according to commercial practices. Immune measurements included weight and percentage of total body mass of the spleen, thymus and bursa of Fabricius, and responses to Sheep Red Blood Cell (SRBC) injection and vaccine titers for Newcastle Disease Virus (NDV), Infectious Bursal Disease Virus (IBDV) and Infectious Bronchitis Virus (IBV). In a completely randomised design, a total of 200 Ross 308 broiler chickens were assigned to four replicates (10 chicks) for each of five dietary treatments: $4 \%$ beef tallow; $4 \%$ canola oil; $4 \%$ sunflower oil, $2 \%$ beef tallow and $2 \%$ canola oil; and $2 \%$ beef tallow and $2 \%$ sunflower oil.

Thymus weight and percentage and bursa of Fabricius percentage were influenced $(\mathrm{P}<0.05)$ by dietary fat source; however, bursa of Fabricius weight and spleen weight and percentage were not affected by treatments. Dietary fat source had no impact $(\mathrm{P}>0.05)$ on the humoral immune response to SRBC injections, or to NDV, IBDV or IBV vaccinations. From our findings, it appears that further research possibly at the fatty acid level, is required before diet fat manipulation can be used to optimise humoral immunity of broilers.

\section{Key words}

Broiler, nutrition, dietary fat, immune response, vaccines, viral diseases

\section{Zusammenfassung}

Einfluss der Futterfettquelle auf die humorale Immunantwort von Broilern

Das Ziel der Studie war die Untersuchung des Einflusses von unterschiedlichen Futterfettquellen auf die Immunreaktion von kommerziell gehaltenen Broilern. Die Charakterisierung des Immunstatus erfolgte anhand der absoluten und relativen (bezogen auf die Lebendmasse) Gewichte von Milz, Thymus und Bursa fabritius sowie anhand der Reaktion auf eine Injektion von Schaferythrozyten (SRBC) und der Impftiter gegen das Newcastle Disease Virus (NDV), das Infektiöse Bursa Disease Virus (IBDV) sowie das Infektiöse Bronchitis Virus (IBV). Es wurde eine vollständig randomisiertes Versuchsdesign mit 5 Behandlungen gewählt: 4\% Rindertalg, 4\% Rapsöl, 4\% Sonnenblumenöl, 2\% Rindertalg + 2\% Rapsöl, 2\% Rindertalg + 2\% Sonnenblumenöl. Jede Behandlung wurde viermal wiederholt (a 10 Tiere).

Die Futterfettquelle beeinflusste signifikant das Gewicht und den Anteil des Thymus sowie den Anteil der Bursa fabritius $(\mathrm{P}<0,05)$. Dagegen wirkten sich die Behandlungen nicht auf das Gewicht der Bursa fabritius und das Gewicht sowie den Anteil der Milz aus. Die Futterfettquelle hatte ferner keinen Einfluss auf die humorale 
Immunantwort auf die Injektion der Schaferythrozyten oder die Impfungen gegen NDV, IBDV und IBV. Die bisherigen Ergebnisse deuten darauf hin, dass weitere Untersuchungen auf der Fettsäureebene erforderlich sind, bevor eine optimale Fettquelle zur Optimierung der humoralen Immunität empfohlen werden kann.

\section{Stichworte}

Broiler, Fütterung, Futterfett, Immunantwort, Impfstoffe, Virale Erkrankungen

\section{Acknowledgements}

This manuscript summarises the MSc. thesis of first author. The authors are grateful to the Rasht Branch, Islamic Azad University, Rasht, Iran for support.

\section{References}

AOAC, 2000: Official methods of analysis. 17th edn. Association of Official Analytical Chemists, Washington DC, USA.

BAIAO, N.C., L.J.C. LARA, 2005: Oil and fat in broiler nutrition. Braz. J. Poult. Sci. 7, 129-141.

DonohuE, M., D.L. CUnNIngham, 2008: Effects of grain and oilseed prices on the costs of US poultry production. J. Appl. Poult. Res. 18, 325-337.

EnSminger, M.E., C.G. Olentine, 1980: Feed and nutrition, 1st ed., Ensminger Publ., Colvis.

FRITSCHE, K.L., N.A. CASSITY, 1992: Dietary n-3 fatty acids reduce antibody-dependent cell cytotoxicity and alter eicosanoid release by chicken immune cells. Poult. Sci. 71, 1646-1657.

HARRISON, L.M., K.V. BALAN, U.S. BABU, 2013: Dietary fatty acids and immune response to food-borne bacterial infections. Nutrients 5, 1801-1822.

HOSSEINI-MANSOUB, N., Y. BAHRAMI, 2011: Influence of fish oil supplementation on humoral immune response and some selected biochemical parameters of broiler chickens. J. Agrobiol. 28, 67-77.

KAMran, A.S., S. RAHIMI, M.A. KARIMI TORSHIZI, 2009: Effect of dietary oil seeds on n-3 fatty acid enrichment, performance parameters and humoral immune response of broiler chickens. Iran. J. Vet. Res. 10, 158-165.

KIDD, M.T., 2004: Nutritional modulation of immune function in broilers. Poult. Sci. 83, 650-657.

Laudadio, V., A. Dambrosio, G. Normanno, R.U. Khan, S. NAZ, E. Rowghani, V. Tufarelli, 2012: Effect of reducing dietary protein level on performance responses and some microbiological aspects of broiler chickens under summer environmental conditions. Avian Biol. Res. 5, 88-92.

LeESON, S., J.D. Summers, 2001: Scott's Nutrition of the Chicken. 4th edn University Books, Guelph, Ontario, Canada.

Murugesan, G.R., 2013: Understanding the effectiveness of blended fats and oils in poultry diets. Anim. Ind. Rep. $659,55$.

Newman, R.E., W.L. Bryden, E. Fleck, J.R. Ashes, W.A. ButTemer, L.H. Storlien, J.A. Downing, 2002: Dietary n-3 and n-6 fatty acids alter avian metabolism: metabolism and abdominal fat deposition. Brit. J. Nutr. 88, 11-18.

NRC, 1994: Nutrient Requirements of Poultry, 9th rev. ed., National Research Council, Washington, USA.

NTAMBI, J.M., Y. CHOI, Y. PARK, J.M. PeTERS, M.W. PARIZA, 2002: Effects of conjugated linoleic acid (CLA) on immune responses, body composition and stearoyl-CoA desaturase. Can. J. Appl. Physiol. 27, 617-627.

Pilevar, M., J. ARshami, A. Golian, M.R. BASAmi, 2011: Effects of dietary n-6:n-3 ratio on immune and reproductive systems of pullet chicks. Poult. Sci. 90, 1758-1766.

Poorghasemi, M., A. SeidAVI, A.A.A. Qotbi, V. LAUdAdio, V. Tufarelli, 2013: Influence of dietary fat source on growth performance responses and carcass traits of broiler chicks. Asian-Austral. J. Anim. Sci. 26, 705-710. 
ROTTER, B., W. GUENTER, B.R. BOyCOTT, 1985: Sudden death syndrome in broilers: Dietary fat supplementation and its effect on tissue composition. Poult. Sci. 64, 1128-1136.

SANZ, M., A. FLORES, C.J. LOPEZ-BOTE, 2000: The metabolic use of energy from dietary fat in broilers is affected by fatty acid saturation. Brit. Poult. Sci. 41, 61-68.

SHIVAZAD, M., A.R. SeIDAVI, 2006: Poultry Nutrition. Tehran University Press, Iran.

TORKI, M., 2002: Effects of n-3 and n-6 fatty Brpaskh broilers immune and inflammatory. Faculty of Agriculture, Mashhad, PhD thesis, Mashhad, Iran.

VAN DeR Klis, J.D., C. KwAKeRnAaK, A. JANSMAn, M. BloK, 2010: Energy in poultry diets: adjusted AME or net energy. Aust. Poult. Sci. Symp. 21, 44-49.

WANG, Y.W., C.J. FIELD, J.S. SIM, 2000: Dietary polyunsaturated fatty acids alter lymphocyte subset proportion and proliferation, serum IgG concentration and immune tissue development in chicks. Poult. Sci. 80, 1741-1748.

Correspondence: Dr. Vincenzo Tufarelli, Department of Emergency and Organ Transplantation, Section of Veterinary Science and Animal Production, University of Bari ‘Aldo Moro’, Valenzano, Italy; Email: vincenzo.tufarelli@uniba.it 